\title{
Living in the intertidal: desiccation and shading reduce seagrass growth, but high salinity or population of origin have no additional effect
}

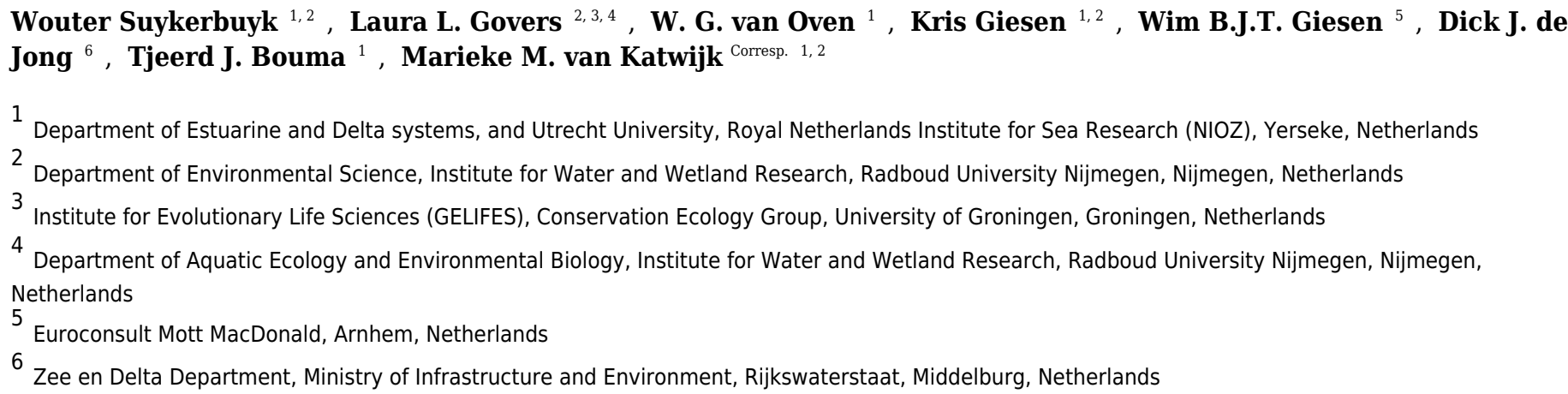

The limiting effects of stressors like desiccation, light and salinity on seagrass growth and distribution are well-studied. However, little is known about their interactive effects, and whether such effects might differ among populations that are adapted to different local conditions. In two laboratory experiments we tested a) if growth and development of intertidal, temperate Zostera noltii is affected by emergence time (experiment 1 and 2), and b) how this is affected by an additional, second stressor, namely shading (experiment 1 ) or high salinity $(25,30$ and 35 , experiment 2$)$. In addition, we tested c) whether the effects of emergence time and salinity varied between three different European seagrass populations (Saint-Jacut / France, Oosterschelde / The Netherlands, and Sylt / Germany), which are likely adapted to different salinity levels (experiment 2). In both experiments, emergence of 8 hours per tidal cycle (of 12 hours) had a negative effect on seagrass relative growth rate (RGR), and aboveground biomass. Emergence furthermore reduced either rhizome length (experiment 1 ) or belowground biomass (experiment 2). Shading (experiment 1) resulted in lower RGR and a two-fold higher aboveground / belowground ratio. We found no interactive effects of emergence and shading stress. Salinity (experiment 2) did not affect seagrass growth or morphology of any of the three populations. The three tested populations differed greatly in morphology but showed no differential response to emergence or salinity level (experiment 2). Our results indicate that emergence time and shading show an additive negative effect (no synergistic or antagonistic effect), making the plants still vulnerable to such combination, a combination that may occur as a consequence of self-shading during emergence or resulting from algal 
cover. Emergence time likely determines the upper limit of $Z$. noltii and such shading will likely lower the upper limit. Shading resulted in higher aboveground / belowground ratios as is a general response in seagrass. $Z$. noltii of different populations originating from salinity 30 and 35 seem tolerant to variations in salinity within the tested range. Our results indicate that the three tested populations show morphotypic rather than ecotypic variation, at least regarding the salinity and emergence, as there were no interactive effects with origin. For restoration, this implies that the salinity regime of the donor and receptor site of $Z$. noltii is of no concern within the salinity range 25-35. 
1 Title:

2 Living in the intertidal: desiccation and shading reduce seagrass growth, but high salinity or

3 population of origin have no additional effect

4

\section{Authors:}

6 Wouter Suykerbuyk ${ }^{1,2}$, Laura L. Govers ${ }^{1,3,4}$, W. G. van Oven ${ }^{1}$, Kris Giesen ${ }^{1,2}$, Wim B.J.T.

7 Giesen ${ }^{1,5}$, Dick J. de Jong ${ }^{6}$, Tjeerd J. Bouma ${ }^{2}$, Marieke M. van Katwijk ${ }^{1,2}$

8

$9 \quad{ }^{1}$ Department of Estuarine and Delta systems, and Utrecht University, Royal Netherlands

Institute for Sea Research (NIOZ), Yerseke, Netherlands

$11{ }^{2}$ Department of Environmental Science, Institute for Water and Wetland Research, Radboud

12 University Nijmegen, Nijmegen, Netherlands

$13{ }^{3}$ Institute for Evolutionary Life Sciences (GELIFES), Conservation Ecology Group, Groningen,

14 University of Groningen, Groningen, Netherlands

${ }^{4}$ Department of Aquatic Ecology and Environmental Biology, Institute for Water and Wetland

Research, Radboud University Nijmegen, Nijmegen, Netherlands

17

20

21

22 Middelburg, Netherlands

${ }^{5}$ Euroconsult Mott MacDonald, Arnhem, Netherlands

${ }^{6}$ Zee en Delta Department, Ministry of Infrastructure and Environment, Rijkswaterstaat,

Corresponding author:

Marieke M. van Katwijk, Email: m.vankatwijk@science.ru.nl, Telephone: +31-6-52217567 


\section{Abstract}

24 The limiting effects of stressors like desiccation, light and salinity on seagrass growth and distribution are well-studied. However, little is known about their interactive effects, and whether such effects might differ among populations that are adapted to different local conditions. In two laboratory experiments we tested a) if growth and development of intertidal, temperate Zostera noltii is affected by emergence time (experiment 1 and 2), and b) how this is affected by an additional, second stressor, namely shading (experiment 1 ) or high salinity $(25,30$ and 35 , experiment 2). In addition, we tested c) whether the effects of emergence time and salinity varied between three different European seagrass populations (Saint-Jacut / France, Oosterschelde / The Netherlands, and Sylt / Germany), which are likely adapted to different salinity levels (experiment 2).

In both experiments, emergence of 8 hours per tidal cycle (of 12 hours) had a negative effect on seagrass relative growth rate (RGR), and aboveground biomass. Emergence furthermore reduced either rhizome length (experiment 1) or belowground biomass (experiment 2). Shading (experiment 1) resulted in lower RGR and a two-fold higher aboveground / belowground ratio. We found no interactive effects of emergence and shading stress. Salinity (experiment 2) did not affect seagrass growth or morphology of any of the three populations. The three tested populations differed greatly in morphology but showed no differential response to emergence or

41 salinity level (experiment 2).

42 Our results indicate that emergence time and shading show an additive negative effect (no 43 synergistic or antagonistic effect), making the plants still vulnerable to such combination, a 44 combination that may occur as a consequence of self-shading during emergence or resulting 45 from algal cover. Emergence time likely determines the upper limit of $Z$. noltii and such shading 
46 will likely lower the upper limit. Shading resulted in higher aboveground / belowground ratios as

47 is a general response in seagrass. Z. noltii of different populations originating from salinity 30

48 and 35 seem tolerant to variations in salinity within the tested range. Our results indicate that the

49 three tested populations show morphotypic rather than ecotypic variation, at least regarding the

50 salinity and emergence, as there were no interactive effects with origin. For restoration, this

51 implies that the salinity regime of the donor and receptor site of $Z$. noltii is of no concern within

52 the salinity range $25-35$.

53

54

55

56

57

58

59

60

61

62

63

64

65

66

67 2016).

Desiccation due to air exposure imposes a stress to marine life in the intertidal zone.

Whereas mobile species can escape to moist places during low tide, sessile intertidal organisms need to cope with hours of air exposure. In the seagrass species Zostera noltii, short periods of air exposure are utilized to its advantage to assimilate $\mathrm{CO}_{2}$, as long as the leaves remain moist (Leuschner et al. 1998). However, adverse effects of emergence rapidly increase with duration to air. Emergence periods of only 5 hours air exposure per tide may result in a $50 \%$ water loss in the leaves, concomitant with 50\% reduction in photosynthetic rates (Leuschner et al. 1998). Besides the physiological effects of drought stress, desiccation of the leaves after low tide exposure decreases the mechanical strength and subsequently the probability of leaf sloughing (Vermaat et al. 1993). In addition, this may result in shorter leaf lengths as desiccated leaf points are prone to break, resulting in a decreased capacity of photosynthesis (Boese et al. 2003), and reduced water retention by the leaves (e.g. Fox 1996), which is density dependent (de Fouw et al. 
Desiccation is usually the limiting factor controlling the upper limit of seagrass growth on

69

70

71

72

73

74

75

76

77

78

the intertidal flat (Philippart \& Dijkema 1995; Leuschner et al. 1998; van Katwijk \& Hermus 2000; van der Heide et al. 2010). However, risk of desiccation varies over tides, days, seasons and latitude (i.e. Perez-Llorens \& Niell 1993), and actual emergence stress will depend on the temperature, wind conditions, sediment water content and seagrass density. For example, although intertidal Z. noltii in the sub-tropical Mauretania has to cope with an air temperature of $40^{\circ}$ Celsius during six hours of emergence per tide, meadows still have high $(>75 \%$ coverage $)$ shoot density due to the facilitating effects of such high densities on water retention of meadows (de Fouw et al. 2016). On the other hand, the productivity during emersion is lower than during submergence in these beds (Clavier et al. 2011), which was also found in more temperate beds at the atlantic coast of France (Quisse et al. 2011). In both cases, this was largely attributed to selfshading by the leaves laying flat, covering each other in the dense beds. It may seem counterintuitive that light could be limiting in an intertidal bed, but in addition to self-shading, also very turbid water may limit productivity during the high tide hours, and cover by epiphytes and green macroalgae can be severe in intertidal beds, particularly since seagrasses facilitate the presence of these algae by providing substrate and shelter (Michael et al. 2008).

In temperate regions, light availability varies over the year and controls the start and end of rhizome branching during the growing season (Vermaat \& Verhagen 1996, Govers et al. 2015).Photo-inhibition is not likely, as Z. noltii is very tolerant to high light levels (Jimenez et al. 1987), also in combination with emergence (Clavier et al. 2011, Ouisse et al. 2011). To compensate for light limitation, shading typically results in an increased aboveground / belowground biomass ratio with longer shoots compared to plants grown in ambient light conditions (e.g. Abal et al. 1994; Philippart 1995; Vermaat et al. 2000; Peralta et al. 2002). 
91 Longer shoots may however make intertidal seagrass plants more vulnerable to desiccation when 92 growing at low density.

93 In general, several stressors may cause a conditional outcome of emergence stress. For 94 example, in addition to light limitation due to self-shading or algal cover mentioned above, a 95 stress like a high salinity may influence the tolerance to desiccation. Salinity stress could be one 96 of the most ubiquitous stressors that marine life and thus also seagrasses encounter. Marine 97 macrophytes can counteract osmotic stress on the short-term by internal adjustments of turgor-

98 pressure by up- and down-regulation of simple ions and on the long-term by synthesis or 99 breakdown of osmotically active compounds (Touchette 2007). Both physiological mechanisms require energy and could therefore reduce plant fitness. A salinity range as wide as 10 to 35 does 101 not cause increased mortality in seagrass Zostera marina (Kamermans et al. 1999; van Katwijk et al. 1999; Nejrup et al. 2008), whereas salinities of 5 and lower increase mortality (Nejrup et al. 2008). With increasing temperature, salinity stress effects become even more pronounced

104 (Salo \& Pedersen 2014). Within the non-mortal salinity conditions, a salinity range of 22-23 was

105 found to be the optimal ex situ for temperate eelgrass Z. marina. That is, at this salinity

106 maximum production of shoots and leaves was found whereas growth and vitality were reduced 107 at higher salinities (>26) (Kamermans et al. 1999; van Katwijk et al. 1999). Plants of Z. marina 108 populations grown under high salinity seem to better cope with high salinity than plants 109 originating from an estuarine or other low salinity habitat (van Katwijk et al. 1998; van Katwijk 110 et al. 1999), and reversely, low-salinity grown plants tolerate lower salinities than high salinity 111 grown plants (Salo et al. 2014). Also, in Posidonia oceanica distinct differences in response to 112 salinity between plants from different origins are found (Fernandez-Torquemada \& Sanchez113 Lizaso 2005). In Z. noltii, different origins were tested on high salinity tolerance, comparing 15 
114 and 35 (Vermaat et al. 2000). Responses to salinity stress are similar to those of Z. marina:

115 increased mortality was found at extreme salinities (e.g. Vermaat et al. 2000; Charpentier et al.

116 2005). To our knowledge, the more subtle salinity preferences of $Z$. marina plants of different

117 origins described above were never tested for $Z$ noltii. The outcome of such tests can be

118 important for restoration projects with different donors originating from different salinities. Since

119 critical mass is very important for seagrass restoration success (van Katwijk et al. 2016), focus

120 should not only be on surviving certain salinities but also about highest growth rates.

121 Although separate effects of desiccation, light and salinity stress are relatively well

122 studied, little is known about the interactive effects of these stressors, in other words, whether

123 they show an additive effect (= no interaction), or may act synergistic or antagonistic (=

124 interaction), and if these effects differ among populations that are adapted or acclimatized to

125 different local conditions (but see Vermaat et al. 2000). Thus, we want to test if the growth rate

126 and morphology of the intertidal $Z$. noltii are negatively affected by emergence, and whether its

127 effect is strengthened by the presence of an additional second stressor: shading or high salinity.

128 In addition, we want to test whether the effects of emergence and salinity vary between Z. noltii

129 populations from three different origins in western Europe, which are possibly adapted to

130 different local salinity levels. We hypothesize that 1) Emergence has a negative effect on the

131 growth rate and size of the intertidal temperate Zostera noltii (H1). 2) Growth is further reduced

132 when an additional stressor, i.e. shading or high salinity is present (H2), and shading will result

133 in higher aboveground biomass and longer leaves as is commonly found, e.g. de los Santos et al.

$1342010(\mathrm{H} 2 \mathrm{~b})$. And 3) Seagrass origin determines the salinity stress response; plants of populations

135 that grow under high salinity will be less affected in their growth and morphology response than

136 those of low-salinity populations (H3). 


\section{Material and methods}

139 Experiment 1

To test emergence period and shading and their interaction on Zostera noltii, we examined seagrass growth in a range of four emergence periods $(0,4,6$ and 8 hours per $12 \mathrm{~h})$, under control or shaded light conditions. Plants were collected from the Goese Sas tidal flat, Oosterschelde basin, SW Netherlands (51 $31.40^{\prime} \mathrm{N} ; 3^{\circ} 56.37^{\prime} \mathrm{E}$; average salinity of 29.5) (Fig. 1), with permission of the Province of Zeeland (case NB08.068, reference 08033625), transported free floating and stored free-floating in a container with sand-filtered water (salinity of $30,17^{\circ} \mathrm{C}, 210 \mu \mathrm{E} \mathrm{m} \mathrm{m}^{-2} \mathrm{~s}^{-1} 14 \mathrm{~h}$ per day) during 3 days before the start of the experiment at 21 July 2011. Each experimental planting unit (EPU) consisted of the apical shoot (\#1), shoot \#2, the internode between shoot \#1 and \#2 and $1 \mathrm{~cm}$ of the appending internode between shoot \#2 and the cut off shoot \#3 (Fig. 2). 80 EPUs were weighed (wet) and separately planted in small trays $(20 \times 9.5 \times 12 \mathrm{~cm})$ filled with an sand/ silt mixture (median grain size $169 \mu \mathrm{m})$ from a tidal flat near Bath, Westerschelde estuary, The Netherlands. By having only one EPU per tray, consisting of two shoots, minimal self-shading occurs during emergence. Four trays were in each overflow aquaria $(50 \times 39 \times 26 \mathrm{~cm})$. Four aquaria, each having a different emergence period, were placed in one container; in total 5 replicate containers were used (so 5 replicates, 4 treatments and 4 pseudoreplicates; set-up see Fig. 2) Overflow was created by pumping (3001/h) sand-filtered Oosterschelde water from the container into the bottom of each aquarium, whereupon water returned into the container. The experimental emergence periods of the seagrass $(0,4,6$, or $8 \mathrm{~h}$ per $12 \mathrm{~h}$ ) were created by automatically switching off the circulation pump, after which the 
160 the natural desiccation gradient (ranging from no desiccation to extreme desiccation): 0h:

161 subtidal zone (Z. noltii grows in this zone in Basque country and Portugal; Valle et al. 2011 and

162 Cunha et al. 2013, respectively), 4h: lower intertidal seagrass zone in the Oosterschelde; 6h:

163 average $Z$. noltii emergence period in the Oosterschelde, 8h: the upper extreme of $Z$. noltii

164 distribution in the Oosterschelde. Light $\left(217 \pm 31 \mu \mathrm{E} \mathrm{m}^{-2} \mathrm{~s}^{-1}\right)$ was produced by beams of LED-

165 lights emitting a photo spectrum with peaks at 450 (blue) and 670 (red) nm, a spectrum

166 optimized to emit the absorption spectrum for plant photosynthesis. To create low light

167 conditions $\left(51 \pm 10 \mu \mathrm{E} \mathrm{m}^{-2} \mathrm{~s}^{-1}\right)$, black neutral density filters (which reduce the intensity of all

168 wavelengths of light equally, attenuation coefficient of 0.76 screen $^{-1}$ ) were placed over half of

169 each aquarium. The photoperiod was set at 14 hours of light per day, with one emergence period

170 during the light period and one emergence period was during the dark period. The temperature of

171 the climate controlled room was set at $17^{\circ} \mathrm{C}$. These abiotic settings resemble natural conditions at

172 the beginning of the experiment. Epiphytes (if any) were gently removed weekly. Every week,

173 the entire volume of water of each of the five water containers was refreshed to maintain

174 constant water quality (i.e. salinity, nutrients, etc.) among the 4 replicates within the containers.

175 At the end of the experiment ( $\mathrm{t}=92$ days), EPUs were harvested after which their growth

176 response to the treatments was determined by measuring their weight (aboveground and

177 belowground parts separately) and morphology. Relative growth rate (RGR) was based on EPUs

178 wet weight (WW, in grams) and was calculated as: $\mathrm{RGR}=\left(\ln \mathrm{WW}_{\text {end }}-\ln \mathrm{WW}_{\text {start }}\right) /(\Delta \mathrm{t}), \Delta \mathrm{t}$ is the 179 running time of the experiment in days.

180 Experiment 2

181 To test the effect of emergence, population of origin and salinity and their interaction on

182 Z. noltii, we examined seagrass growth of plants originating from three temperate seagrass 
183 populations, at two emergence periods, in three natural range salinities. Plants were collected

184 from three locations in western Europe: Saint-Jacut, (Brittany, France), 48 36 14. 79" N, $2^{\circ}$

185 11'41. 49" W, average salinity of 34.7, Oosterschelde (Southwest Netherlands), 51 ${ }^{\circ} 53^{\prime 20}$. 58" N,

$1863^{\circ} 93^{\prime} 88.35^{\prime \prime}$ E, average salinity of 29.5 and Sylt (Wadden Sea, Germany), 54 47'50.77" N, $8^{\circ}$

187 17'43.87" E, average salinity of 29.9 (Fig. 1). At all three locations, water is relatively clear,

188 namely Saint Jacut:, $1.5-2$ m secchi depth (2 - 4 Formazin Nephelometric Units; Ifremer 2014),

189 Oosterschelde: $1.50 \mathrm{~m}$ secchi depth (Data Ministry of Infrastructure and Water Management

190 2002-2009) and Sylt: $1-3.5 \mathrm{~m}$ secchi depth $\left(0.5-1.9 \mathrm{~m}^{-1}\right.$ light attenuation coefficient at an

191 average tidal range of 1.7m; van Katwijk et al. 1998 and frequent personal observation second

192 and last author in later years). Plants from Sylt and Saint Jacut were transported to the laboratory

193 within $24 \mathrm{~h}$, stored in wet tissues, kept at $6^{\circ} \mathrm{C}$ temp. Plants from Oosterschelde were transported

194 free floating within 3 h. Upon arrival, they were replanted in the laboratory to acclimatize during

1952 months in the same sediments as in experiment 1, in sand-filtered Oosterschelde water (salinity

196 of $31-32,17^{\circ} \mathrm{C}, 210 \mu \mathrm{E} \mathrm{m}^{-2} \mathrm{~s}^{-1} 14 \mathrm{~h}$ per day) until the start of the experiment on 30 September

197 2011, (which is at the end of the growing season in the field, but previous studies had shown

198 vigourous growth of this perennial plant during autumn in the laboratory, Han et al. 2012).

199 Except for the applied treatments, the experimental set-up resembled that of the first experiment,

200 i.e. same EPUs characteristics, planting trays, overflow aquaria, emergence methods, plant care,

201 artificial lighting, light/ dark cycle and climate controlled temperature were used. In this

202 experiment, 2 containers per salinity treatment were used, in each container 4 aquaria were

203 placed with either 0 or $8 \mathrm{~h}$ emergence per $12 \mathrm{~h}$, and within each aquarium 3 pseudoreplicates for

204 each population of origin (Fig. 2). EPUs of each population were weighted wet. To test the

205 response of seagrass to different salinities, overflow aquaria were filled with seawater with a 
206 salinity of 25,30 or 35 . Seawater with a salinity of 25 was obtained by mixing demineralized

207 water to the ambient (salinity of 30) seawater, whereas a salinity of 35 was obtained by adding

208 artificial seasalt (Instant Ocean ${ }^{\circledR}$ Sea Salt, http://www.instantocean.com). pH was assumed not to

209 be influenced by the dilution with demineralized water (as was found in a salinity experiment

210 described in van Katwijk et al. 1999; pH data of this experiment are presented in supplementary

211 Table 1). To maintain stable salinity levels, salinity was checked at least twice a week and if

212 needed adjusted by adding demineralized water to compensate for evaporation. The water of

213 each container was refreshed after 5 weeks. Nutrient levels of the water were measured after 28

214 and 61 days and showed no correlation with salinity treatments (supplementary Table 2). EPUs

215 were evenly divided over all treatments $(n=2$ true replicates $x 3$ pseudo replicates $\times 2$ emergence

216 replicates $=12$ per treatment $)$. At the end of the experiment ( $\mathrm{t}=75$ days $),$ EPUs were harvested

217 and measured for weight (aboveground and belowground parts separately) and morphology to

218 determine their growth response. Relative growth rate (RGR) was based on EPUs wet weight

219 (WW, in grams) and was calculated as: $\mathrm{RGR}=\left(\ln \mathrm{WW}_{\text {end }}-\ln \mathrm{WW}_{\text {start }}\right) /(\Delta \mathrm{t}), \Delta \mathrm{t}$ is the running

220 time of the experiment in days.

\section{Statistical analysis}

222 The results of experiment 1 were analysed by linear mixed models with light and emergence

223 time as fixed factors. As aquaria were nested within containers (Fig. 2) and EPUs within one

224 aquarium consisted of pseudoreplicates, we included aquarium nested in container

225 (container/aquarium) as a random factor in our models. Rhizome length, shoot length,

226 aboveground biomass, belowground biomass, total biomass, relative growth rate (RGR) and

227 aboveground / belowground biomass ratio were analyzed by general linear mixed models (lme, 
228 nlme package, R 3.2.3) and shoot numbers by a generalized linear mixed model with a Poisson

229 distribution (glmer, lme4 package, R 3.2.3).

230 The results of experiment 2 were also analysed by mixed models with emergence, salinity and

231 origin as fixed factors. Similar to the set-up of experiment 1, aquaria were nested in containers

232 (Fig. 2) and we thus included container/aquarium nested as a random factor in our models.

233 Longest shoot length, rhizome length, aboveground biomass, belowground biomass, total

234 biomass, relative growth rate (RGR, ) and aboveground / belowground biomass ratio were

235 analysed general linear mixed models (lme, nlme package, R 3.2.3) and shoot numbers by a

236 generalized linear mixed model with a poisson distribution (glmer, lme4 package, R 3.2.3 (C) R

237 Core Development Team).

238 Normal distribution of all data was tested on model residuals by means of a Shapiro test and by

239 looking at the histogram, and data were log- or square root-transformed to meet model

240 assumptions if necessary.

\section{Results}

243 Desiccation stress (emergence) significantly reduced aboveground biomass (Fig. 3A, $P=$ $2440.010)$ and relative growth rate (Fig. 3F, $P=0.045)$ (Table 1); aboveground biomass was

245 reduced by $27 \%$ and relative growth rate by $32 \%$ in the $8 \mathrm{~h}$ emergence time treatment compared 246 to the completely submerged treatment ( $0 \mathrm{~h}$ emergence time). In line with this, emergence also

247 significantly reduced rhizome length (Fig. 3G, $P=0.049$ ) in the 6 and 8 h emergence treatment 248 by $26-28 \%$. Next to desiccation stress, Shading (light reduction) also significantly reduced the 249 relative growth rate (Fig $3 \mathrm{~F}, P=0.039)$ by $18 \%$. In addition, shading significantly reduced 250 belowground biomass by $33 \%$ (Fig. 3B, $P<0.001)$ and total biomass by $23 \%(P=0.010)$, 
251 thereby strongly increasing the aboveground/belowground biomass ratio (Fig. 3D, $P<0.001$ ).

252 Plant morphology also changed significantly under light limitation stress; leaves grew 21\%

253 longer when shaded (Fig. 3H, $P=0.011$ ). Although we found clear effects of desiccation and

254 shading stress on growth (Relative growth rate, biomass) and morphology (leaf length and

255 rhizome length), we did not observe any interactive effects of desiccation and light limitation

256 stress.

257 The second experiment included exposing Z. noltii from three different locations in

258 Western Europe (France, the Netherlands, Germany) to desiccation stress ( 0 vs. $8 \mathrm{~h}$ emergence)

259 and three different salinities $(25,30,35 \mathrm{ppt})$. Similar to the first experiment, we found that

260 desiccation stress ( $8 \mathrm{~h}$ emergence) reduced relative growth rate (Fig. 4F, $P<0.001$ ) and

261 aboveground biomass (Fig. 4A, $P=0.003$ ) by $25 \%$ and $19 \%$ respectively (Table 2 ). In addition,

262 belowground biomass (Fig. 4B, $P<0.001)$ and total biomass $(P=0.001)$ were also reduced by

263 desiccation stress by $32 \%$ and $29 \%$ (Table 2 ). Location of origin affected morphology and

264 biomass of the plants; rhizomes (Fig. 4G, $P<0.001$ ) and leaves (Fig. 4H, $P<0.001$ ) were smaller

265 and aboveground (Fig. 4A, $P<0.001$ ), belowground (Fig. 4B, $P<0.001$ ) and total biomass (Fig

$2664 \mathrm{C}, P<0.001$ ) lower in a gradient from France (Saint Jacut) to Germany (Sylt) (Table 2). Leaves

267 and rhizomes from the French Z. noltii were 22\% longer than the German plants and above- and

268 belowground biomass was approximately 2.4 times larger as compared to Sylt plants at the end

269 of the experiment (pooled results, Fig. 4). As RGR did not differ between the origins of the

270 populations (e.g. RGR of Saint Jacut was 1.06 times the RGR of Sylt), the size differences at the

271 end of the experiment reflect the differences at the beginning of the experiment. Similar plant

272 size differences between these populations are observed in other years or seasons (Soissons et al.

273 2018, Govers et al. in press). Plants originating from the Netherlands (Oosterschelde) were in the 
274 middle for all measured traits. In addition, total shoot numbers were also significantly higher

275 (Fig. 4E, $P=0.004$, Table 2) in units with plants from France than in units with Dutch and

276 German plants. Despite these differences in morphology and biomass, seagrass plants from

277 different origins were similarly affected by emergence and salinity as we found no interactive

278 effects for any of our parameters (salinity* origin * emergence). Surprisingly, we found no

279 effect of our salinity treatment on any growth or morphological parameters, indicating a broad

280 salt tolerance of Z. noltii (Table 2).

281

282

\section{Discussion}

Emergence had a negative effect on seagrass growth in both experiments confirming our hypothesis (H1). Increasing duration of air exposure hampered seagrass growth, reflected by a smaller RGR and reduced aboveground biomass of the plants as compared to the control group that was never subjected to emergence. The reduced growth might be the consequence of loss of photosynthetic capacity due to desiccation damage to the leaves (Leuschner et al. 1998; Vermaat et al. 2000; Fernandez-Torquemada \& Sanchez-Lizaso 2005; Shafer et al. 2007). In the field, the negative effect of desiccation was demonstrated by the higher biomass found in depressions (which retain water during low tide) as compared to elevations (dry at low tide) within the same bed (van Tussenbroek et al. 2016). Concurrently, these authors found lower sexual reproductive efforts in the depressions, in line with the general notion that reproductive efforts increases with increasing stress in seagrasses (Cabaco and Santos 2012). Further growth reduction from desiccation can be expected in situ as sediment trapping by Z. noltii often causes the plant to grow on elevations, making them more prone to desiccation (Reise \& Kohlus 2008, van der

Heide et al. 2010, van Tussenbroek et al. 2016). Furthermore, desiccation damaged leaves may 
297 be easier torn by waves than undamaged leaves, leaving significantly shorter leaves for

298 photosynthesis (Vermaat et al. 1993; Boese et al. 2003), and reducing water retention by the

299 leaves (e.g. Fox 1996), which is density dependent (de Fouw et al. 2016).

Aboveground/belowground biomass ratio increased (experiment 1), similar to previous studies without emergence treatments (Vermaat et al. 1993; Peralta et al. 2002; Cabaco et al. 2009). Plants apparently invested more in aboveground biomass than in belowground biomass. Confirming our hypothesis (H2), shading added to the negative effect of emergence on RGR. Effects were additive (no interactive effect, so no antagonistic or synergistic effects). The combination is thus more stressful for the plants than singular effects and may explain the strong reduction in net photosynthesis in $Z$. noltii beds during low tide as compared to high tide, due to self-shading by the leaves lying on top of each other during low tide (Clavier et al. 2011, Ouisse et al. 2011). When shading in the intertidal is caused by algal overgrowth, desiccation of the plants during low tide may be less severe as the leaves are kept wet by the algal cover. However, in such cases, suffocation, sulfide and ammonium toxicity pose a threat to seagrasses (Goodman et al. 1995; Den Hartog 1996; Holmer \& Nielsen 2007; Govers et al. 2014). In addition, a stronger reduction in net growth may be expected in the field as the resulting longer leaves experience more wave induced drag force than the shorter leaves that develop under ambient

315 light conditions (Bouma et al. 2005; La Nafie et al. 2012). noltii was not stressed by salinities of 30 and 35 , probably due to its ability to acclimatize to 
320 observed for Z. marina by Kamermans et al. (1999). This is supported by presence of dense $Z$.

321 noltii beds in Banc d'Arguin, Mauritania with salinity levels of over 40 (Vermaat et al. 1993),

322 whereas Z. marina has an optimum at salinities as low as salinity 25 (Nejrup \& Pedersen 2008).

323 Whereas hypothesis H2 (additional stressors aggravate the effects of emergence) was confirmed

324 with regards to shading, it was not confirmed regarding salinity in the range tested. Considering

325 that salinity did not have an effect at all within the tested range, this is not surprising. Perhaps

326 this implies that $Z$. noltii is more of a generalist than a specialist in terms of the environmental

327 extremes it can withstand, making it more of an opportunistic pioneer species instead of a climax

328 community species, as compared to Z. marina.

The effects of salinity and desiccation stress (experiment 2) did not differ between plants

of different origin. This contrasts our expectation that plants that are used to relatively low

salinities would encounter more osmotic stress than those that are already used to relative high

salinity conditions, as was shown for Z. noltii comparing a Spanish and Dutch population in

salinity 15 and 35 (Vermaat et al. 2000) and for Z. marina in a narrower or lower salinity range normally grow at a salinity of 35 grew equally well at salinities of 25 or 30 , and plants used to salinities of 29-30 grew equally well at salinities of 25 or 35 . Perhaps this flexibility may be explained by plants originating from estuarine and shallow coastal conditions (as we used in our experiments) being more used to frequent variations in osmotic stress and thus better able to make fast physiological adaptations, compared to plants from more osmotically stable, true marine environments. Although plants from the three populations differed in plant size and 
342 trend over a broader latitudinal gradient for this species (South Spain to Sylt; Soissons et al.

343 2018), their plant size did not influence their ability to cope with emergence or salinity stress.

\section{Conclusions and ecological implications}

In this study, we found that desiccation stress imposed by emergence and shading have a negative effect on $Z$. noltii. When combined, they show additive effects, there are no synergistic or antagonistic effects. This makes plants vulnerable to such combination (although synergistic effects would enhance this vulnerability even more). The three populations tested show distinctive size difference, but did not respond differentially to emergence and salinity. This indicates that the populations show morphotypic rather then ecotypic variation regarding emergence and salinity, within the range tested. factors than physiological factors (such as predation, competition for space and resources) can also be important under field conditions. The question rises why plants don't grow towards the mean low water level in our research areas, where emergence times are shorter? Our study shows that shorter and absent emergence periods are favourable for Z. noltii. Although seagrass meadows are often light limited at increasing depth (Philippart 1995; Ralph et al. 2007; Cabaco et al. 2009; van der Heide et al. 2010), light is not likely a limiting factor in the habitats of the three tested populations (see Materials and Methods). Probably, water and/or sediment dynamics may explain the absence of Z. noltii in the lower ranges of the intertidal (Suykerbuyk et al. 2016a, b). Still, in more southern ranges of its distribution, Z. noltii occupies the whole intertidal range and expands even in the higher subtidal (e.g. Basque country, Valle et al. 2011, Portugal,

363 Cunha et al. 2013) and submerged in seas where tides are near absent (Mediterranean, Green \& 
364 Short 2003). Further research is required to assess key factors in determining the depth limit of

365 mid-intertidal Z. noltii beds. From our study, it is however clear that (i) emersion period is a

366 factor controlling the upper limit, (ii) shading (for example by self-shading during emersion)

367 likely lowers the upper limit, as the effects shading and emergence were additive, and (iii) this

368 upper limit is not affected by salinity or origin of the population. For restoration purposes, there

369 is no need to carefully select donor populations regarding salinity regime within the range tested,

370 as the plants of different origins (salinity 30 and 35) were not influenced by applied salinities

$371(25,30,35)$.

\section{Acknowledgements}

The authors are grateful to Jan Vermaat for his expert opinion on the initial research

plans. We would also like to acknowledge Ragnhild Asmus and Dominik Kneer (Sylt) and

Laurent Godet and Jérôme Fournier (Saint Jacut) for their cooperation and help in the collection

of Z. noltii. Lastly, we thank Vanessa González-Ortiz for providing the artwork of the experimental plant unit.

\section{References}

Abal E.G., Loneragan N., Bowen P., Perry C.J., Udy J.W. \& Dennison W.C. (1994).

Physiological and morphological responses of the seagrass Zostera-capricorni aschers to light-intensity. Journal of Experimental Marine Biology and Ecology, 178, 113-129. 
384 Boese B.L., Alayan K.E., Gooch E.F. \& Robbins B.D. (2003). Desiccation index: a measure of 385 damage caused by adverse aerial exposure on intertidal eelgrass (Zostera marina) in an Oregon (USA) estuary. Aquatic Botany, 76, 329-337.

387

388

(2005). Trade-offs related to ecosystem engineering: A case study on stiffness of emerging macrophytes. Ecology, 86, 2187-2199.Cabaco S., Machas R. \& Santos R. (2009). Individual and population plasticity of the seagrass Zostera noltii along a vertical intertidal gradient. Estuarine Coastal and Shelf Science, 82, 301-308.

Cabaco S. Santos R (2012) Seagrass reproductive effort as an ecological indicator of disturbance. Ecological Indicators 23: 116-122

Charpentier A., Grillas P., Lescuyer F., Coulet E. \& Auby I. (2005). Spatio-temporal dynamics of a Zostera noltii dominated community over a period of fluctuating salinity in a shallow lagoon, Southern France. Estuarine Coastal and Shelf Science, 64, 307-315.

Clavier J., Chauvaud L., Carlier A., Amice E., van derGest M., Labrosse P., Diagne A., Hily C. (2011) Aquatic Botany, 95, 24-30

Cunha A.H., Assis J.F. \& Serrao E.A. (2013). Seagrasses in Portugal: A most endangered marine habitat. Aquatic Botany, 104, 193-203.

de los Santos, C.B., Brun, F.G., Bouma, T.J., Vergara, J.J., Pérez-Lloréns, L. (10210)

Acclimation of seagrass Zostera noltii to co-occurring hydrodynamic and light stresses. Marine Ecology-Progress Series 398, 127-135.

de Fouw J, Govers LL, van de Koppel J, van Belzen J, Dorigo W, Sidi Cheikh MA, Christianen MJA, van der Reijden KJ, van der Geest M, Piersma T, Smolders AJP, Olff H, Lamers LPM, van Gils JA, van der Heide T (2016) Drought, mutualism breakdown, and 
407

408

409

410

411

412

413

414

415

416

417

418

419

420

421

422

423

424

425

426

427

428

429

landscape-scale degradation of seagrass beds. Current Biology 26 (8), 1051-1056 Den

Hartog C. (1996). Sudden decline of seagrass beds: 'Wasting disease' and other disasters. In: Seagrass Biology: Proceedings of an International Workshop (eds. Kuo J, Phillips RC, D.I. W \& Kirkman H). Sciences UWA Rottnest Island, Western Australia, pp. 307314.

Fernandez-Torquemada Y. \& Sanchez-Lizaso J.L. (2005). Effects of salinity on leaf growth and survival of the Mediterranean seagrass Posidonia oceanica (L.) Delile. Journal of Experimental Marine Biology and Ecology, 320, 57-63.

Fox A.D. (1996). Zostera exploitation by Brent geese and wigeon on the Exe estuary, southern England. Bird Study, 43, 257-268.

Goodman J.L., Moore K.A. \& Dennison W.C. (1995). Photosynthetic responses of eelgrass (Zostera-marina L) to light and sediment sulfide in a shallow barrier-island lagoon. Aquatic Botany, 50, 37-47.

Govers L.L., de Brouwer J.H.F., Suykerbuyk W., Bouma T.J., Lamers L.P.M., Smolders A.J.P., van Katwijk M.M. (2014) Toxic effects of increased sediment nutrient and organic matter loading on the seagrass Zostera noltii. Aquatic Toxicology 155:253-260

Govers L.L., Suykerbuyk W., Hoppenreijs J., Giesen K., Bouma T.J., van Katwijk M.M. (2015) Rhizome starch as indicator for temperate seagrass winter survival. Ecological Indicators $49: 53-60$

Govers LL, Bouma T.J., van den Ent E., Suykerbuyk W., Godet L., van der Heide T., van Katwijk M.M. (almost in press) Feedbacks and local environmental settings affect persistence and recovery dynamics of seagrass beds; alternative reference Govers 2014 Thesis 
430 Green E.P. \& Short F.T. (2003). World Atlas of Seagrasses. University of California Press, Los $431 \quad$ Angeles.

432 Holmer M. \& Nielsen R.M. (2007). Effects of filamentous algal mats on sulfide invasion in 433 eelgrass (Zostera marina). Journal of Experimental Marine Biology and Ecology, 353, 245-252.

435

436

437

438

439

440

441

442

443

444

445

446

447

448

449

450

451

452
Départements d'Ille-et-Vilaine et des Côtes d'Armor. Résultats acquis jusqu'en 2013. Ifremer. Océanographie et Dynamique des Ecosystèmes. Unité Littoral. Laboratoire Environnement Ressources Bretagne Nord, p. 150p.

Jimenez C, Niell FX, Algarra P (1987) Photosynthetic adaptation of Zostera noltii Hornem. Aquatic Botany 29:217-226

Kamermans P., Hemminga M.A. \& de Jong D.J. (1999). Significance of salinity and silicon levels for growth of a formerly estuarine eelgrass (Zostera marina) population (Lake Grevelingen, the Netherlands). Marine Biology, 133, 527-539.

Michael, T.S., Shin, H.W., Hanna, R., Spafford, D.C. (2008) A review of epiphyte community development: Surface interactions and settlement on seagrass. Journal of Environmental Biology, 29, 629-638

La Nafie Y.A., de los Santos C.B., Brun F.G., van Katwijk M.M. \& Bouma T.J. (2012). Waves and high nutrient loads jointly decrease survival and separately affect morphological and biomechanical properties in the seagrass Zostera noltii. Limnology and Oceanography, $57,1664-1672$.

Leuschner C., Landwehr S. \& Mehlig U. (1998). Limitation of carbon assimilation of intertidal Zostera noltii and Z-marina by desiccation at low tide. Aquatic Botany, 62, 171-176. 
453 Nejrup L.B., Brammer L. \& Pedersen M.F. (2008). Effects of salinity and water temperature on 454 the ecological performance of Zostera marina. Aquatic Botany, 88, 239-246.

455 Ouisse V., Migné A., Davoult D. (2011) Community-level carbon flux variability over a tidal 456 cycle in Zostera marina and Z. noltii beds. Marine Ecology-Progress Series, 437, 79-87.

457 Peralta G., Perez-Llorens J.L., Hernandez I. \& Vergara J.J. (2002). Effects of light availability on

458

459

460

461

462

463

464

465

466

467

468

469

470

471

472

473

474 growth, architecture and nutrient content of the seagrass Zostera noltii Hornem. Journal of Experimental Marine Biology and Ecology, 269, 9-26.

Perezllorens J.L. \& Niell F.X. (1993). Temperature and emergence effects on the net photosynthesis of 2 Zostera noltii hornem morphotypes. Hydrobiologia, 254, 53-64.

Philippart C.J.M. (1995). Seasonal-variation in growth and biomass of an intertidal zostera-noltii stand in the dutch wadden sea. Netherlands Journal of Sea Research, 33, 205-218.

Philippart C.J.M. \& Dijkema K.S. (1995). Wax and wane of zostera-noltii hornem in the Dutch Wadden sea. Aquatic Botany, 49, 255-268.

Ralph P.J., Durako M.J., Enriquez S., Collier C.J. \& Doblin M.A. (2007). Impact of light limitation on seagrasses. Journal of Experimental Marine Biology and Ecology, 350, 176193.

Reise K. \& Kohlus J. (2008). Seagrass recovery in the Northern Wadden Sea? Helgoland Marine Research, 62, 77-84.

Salo T. \& Pedersen M.F. (2014). Synergistic effects of altered salinity and temperature on estuarine eelgrass (Zostera marina) seedlings and clonal shoots. Journal of Experimental Marine Biology and Ecology, 457, 143-150. Population specific salinity tolerance in eelgrass (Zostera marina) 
475 Salo T., Pedersen M.F. \& Bostrom, C. (2014). Population specific salinity tolerance in eelgrass (Zostera marina) . Journal of Experimental Marine Biology and Ecology 461, 425-429

477

478

479

480

481

482

483

484

485

486

487

488

489

490

491

492

493

494

495

496

497 vertical distribution of intertidal seagrasses? Aquatic Botany, 87, 161-166.

Soissons L.M.; van Katwijk M.M.; Peralta G.; Brun F.G.; Cardoso P.G.; Grilo T.F.; Ondiviela B.; Recio M.; Valle M.; Garmendia J.M.; Ganthy F.; Auby I.; Rigouin L.; Godet L.; Fournier J.; Desroy N.; Barillé L.; Kadel P.; Asmus R.; Herman P.M.J.; Bouma T.J. (online 2017) Seasonal and latitudinal variation in seagrass mechanical traits across Europe: the influence of local nutrient status and morphometric plasticity Limnology and Oceanography, 63, 37-46.

Suykerbuyk W.; Govers L.L.; Bouma T.J.; Giesen W.B.J.T.; de Jong D.J.; van de Voort R.; Giesen K.; Giesen P.T.; van Katwijk M.M. (2016a) Unpredictability in seagrass restoration: analysing the role of positive feedback and environmental stress on Zostera noltii transplants. Journal of Applied Ecology 53: 774-784

Suykerbuyk W.; Bouma T.J.; Govers L.L.; Giesen K.; de Jong D.J.; Herman P.M.J.; Hendriks A.J.; van Katwijk M.M. (2016b) Surviving in changing seascapes: Sediment dynamics as bottleneck for long-term seagrass presence. Ecosystems 19: 296-310

Touchette B.W. (2007). Seagrass-salinity interactions: Physiological mechanisms used by submersed marine angiosperms for a life at sea. Journal of Experimental Marine Biology and Ecology, 350, 194-215.

Valle M., Borja A., Chust G., Galparsoro I. \& Garmendia J.M. (2011). Modelling suitable estuarine habitats for Zostera noltii, using Ecological Niche Factor Analysis and Bathymetric LiDAR. Estuarine Coastal and Shelf Science, 94, 144-154. 
498 van der Heide T., Bouma T.J., van Nes E.H., van de Koppel J., Scheffer M., Roelofs J.G.M., van 499 Katwijk M.M. \& Smolders A.J.P. (2010). Spatial self-organized patterning in seagrasses $500 \quad$ along a depth gradient of an intertidal ecosystem. Ecology, 91, 362-369.

501 van der Heide T., Peeters E., Hermus D.C.R., van Katwijk M.M., Roelofs J.G.M. \& Smolders A.J.P. (2009). Predicting habitat suitability in temperate seagrass ecosystems. Limnology

van Katwijk M.M. \& Hermus D.C.R. (2000). Effects of water dynamics on Zostera marina: Transplantation experiments in the intertidal Dutch Wadden Sea. Marine Ecology-

van Katwijk M.M., Schmitz G.H.W., Gasseling A.P. \& van Avesaath P.H. (1999). Effects of salinity and nutrient load and their interaction on Zostera marina. Marine Ecology Progress Series, 190, 155-165.

van Katwijk M.M., Schmitz G.H.W., Hanssen L. \& den Hartog C. (1998). Suitability of Zostera marina populations for transplantation to the Wadden Sea as determined by a mesocosm shading experiment. Aquatic Botany, 60, 283-305.

van Katwijk M.M., Thorhaug A., Marbà N., Orth R.J., Duarte C.M., Kendrick G.A., Althuizen I.H.J., Balestri E., Bernard G., Cambridge M.L., Cunha A., Durance C., Giesen W., Han Q., Hosokawa S., Kiswara W., Komatsu T., Lardicci C., Lee K.S., Meinesz A., Nakaoka M., O'Brien K.R., Paling E.I., Pickerell C., Ransijn A.M.A., Verduin J.J. (2016) Global analysis of seagrass restoration: the importance of large-scale planting. Journal of Applied Ecology, 53, 567-578 
521 van Tussenbroek BI, Soissons LM, Bouma TJ, Asmus RM, Auby I, Brun FG, Cardoso PG,

522

523

524

525

526

527

528

529

530

531

532

533

534

535

536

537

538

539

540

541

542

Desroy N, Fournier J, Ganthy F, Garmendia JM, Godet L, Grilo TF, Kadel P, Ondeviela

B, Peralta G, Recio M, Valle M, van der Heide T, van Katwijk MM (2016) Pollen

limitation may be a common Allee effect in marine hydrophilous plants: implications for decline and recovery in seagrasses. Oecologia 182: 595-609

Vermaat J.E., Beijer J.A.J., Gijlstra R., Hootsmans M.J.M., Philippart C.J.M., Vandenbrink N.W. \& Vanvierssen W. (1993). Leaf dynamics and standing stocks of intertidal Zostera noltii hornem - and Cymodocea nodosa (ucria) ascherson on the Banc d'Arguin (Mauritania). Hydrobiologia, 258, 59-72.

Vermaat J.E. \& Verhagen F.C.A. (1996). Seasonal variation in the intertidal seagrass Zostera noltii Hornem: Coupling demographic and physiological patterns. Aquatic Botany, 52, 259-281.

Vermaat J.E., Verhagen F.C.A. \& Lindenburg D. (2000). Contrasting responses in two populations of Zostera noltii Hornem. to experimental photoperiod manipulation at two salinities. Aquatic Botany, 67, 179-189.

Villazan, B., Brun, F.G., Gonzalez-Ortiz, V., Moreno-Marin, F., Bouma, T.J., Vergara, J.J. (2016) Flow velocity and light level drive non-linear response of seagrass Zostera noltei to ammonium enrichment. Marine Ecology-Progress Series, 545, 109-121

Wetsteyn L. \& Kromkamp J.C. (1994). Turbidity, nutrients and phytoplankton primary production in the oosterschelde (the netherlands) before, during and after a largescale coastal engineering project (1980-1990). Hydrobiologia, 283, 61-78. 
Table $\mathbf{1}$ (on next page)

Effects of light and emergence on Zostera noltii 
1 Table 1 Effects of light and emergence on Zostera noltii. Statistical results of Experiment 1.

2 Non-significant test results are marked with "ns", whereas significant test results are marked

3 with “*”. Abbreviations used: Ime = general linear mixed model, gImer = generalized linear

4 mixed model with a Poisson distribution, DF = degrees of freedom, $p=p$-value, DW $=$ dry

5 weight, $\mathrm{WW}=$ wet weight, $\mathrm{AG}=$ above ground biomass, $\mathrm{BG}=$ below ground biomass, $\mathrm{RGR} \mathrm{WW}$

6 = Relative growth rate, $\#=$ number, $\mathrm{L}=$ length, $\mathrm{W}=$ width, $\mathrm{In}=$ natural logarithm, SQRT = square

7 root, log = logarithm.

8

\begin{tabular}{|c|c|c|c|c|c|c|c|}
\hline Factor & test & $\begin{array}{l}\text { Trans- } \\
\text { formation }\end{array}$ & Treatment & F value & DF & $P$ & \\
\hline \multirow[t]{3}{*}{ DW AG } & Ime & $\log$ & light & 3.531 & 1 & 0.060 & n.s. \\
\hline & & & emergence & 11.290 & 1 & 0.010 & $*$ \\
\hline & & & light*emergence & 3.965 & 1 & 0.265 & n.s. \\
\hline \multirow[t]{3}{*}{ DW BG } & Ime & $\log$ & light & 14.728 & 1 & $<0.001$ & $* * *$ \\
\hline & & & emergence & 3.022 & 1 & 0.388 & n.s. \\
\hline & & & light*emergence & 3.597 & 1 & 0.308 & n.s. \\
\hline \multirow[t]{3}{*}{ DW total } & Ime & $\log$ & light & 6.569 & 1 & 0.010 & $*$ \\
\hline & & & emergence & 3.667 & 1 & 0.300 & n.s. \\
\hline & & & light*emergence & 3.498 & 1 & 0.321 & n.s. \\
\hline \multirow[t]{3}{*}{ AG/BG ratio } & Ime & sqrt & light & 52.640 & 1 & $<0.001$ & $* * *$ \\
\hline & & & emergence & 1.560 & 1 & 0.669 & n.s. \\
\hline & & & light*emergence & 2.404 & 1 & 0.493 & n.s. \\
\hline \multirow[t]{3}{*}{ \# shoots } & glmer & - & light & 2.185 & 1 & 0.139 & n.s. \\
\hline & & & emergence & 3.165 & 1 & 0.367 & n.s. \\
\hline & & & light*emergence & 2.545 & 1 & 0.467 & n.s. \\
\hline \multirow[t]{3}{*}{ RGR WW } & Ime & none & light & 4.240 & 1 & 0.039 & $*$ \\
\hline & & & emergence & 8.042 & 1 & 0.045 & $*$ \\
\hline & & & light*emergence & 0.955 & 1 & 0.812 & n.s. \\
\hline \multirow[t]{3}{*}{ Rhizome Length } & Ime & none & light & 0.480 & 1 & 0.489 & n.s. \\
\hline & & & emergence & 7.865 & 1 & 0.049 & $*$ \\
\hline & & & light*emergence & 2.169 & 1 & 0.538 & n.s. \\
\hline \multirow[t]{3}{*}{ Longest shoot } & Ime & $\log$ & light & 6.421 & 1 & 0.011 & $*$ \\
\hline & & & emergence & 1.388 & 1 & 0.708 & n.s. \\
\hline & & & light*emergence & 0.364 & 1 & 0.947 & n.s. \\
\hline
\end{tabular}


Table 2 (on next page)

Results of statistical tests main and combined effects of emergence time 
Table 2 Results of statistical tests testing the main and combined effects of emergence time,

salinity and population origin (location) on seagrass growth and morphology . Non-significant test results are marked with "ns", whereas significant test results are marked with ${ }^{* * *}$ for $P<0.001,{ }^{* *} 0.001<P<0.001$ and ${ }^{*} 0.01<P<0.05$. Abbreviations used: $\mathrm{DF}=$ degrees of freedom, $P=p$-value,$D W=$ dry weight,$W W=$ wet weight,$A G=$ above ground biomass, $B G=$ below ground biomass, RGR WW= Relative growth rate, \# = number, $\mathrm{L}=$ length, $\mathrm{W}=$ width, sqrt = square root, $\log =$ logarithm, Ime = general linear mixed model, glmer = generalized linear mixed model. ${ }^{1}$ Indicates chi-square values of the generalized linear mixed model rather than $F$ values.

\begin{tabular}{|c|c|c|c|c|c|c|c|}
\hline Factor & Test & $\begin{array}{l}\text { Trans- } \\
\text { formation }\end{array}$ & Treatment & DF & F value & $P$ & \\
\hline \multirow[t]{7}{*}{ DW AG } & Ime & sqrt & emergence & 1 & 12.571 & 0.003 & $* *$ \\
\hline & & & salinity & 1 & 4.109 & 0.138 & n.s. \\
\hline & & & origin & 2 & 50.517 & $<0.001$ & $* * *$ \\
\hline & & & emergence*salinity & 2 & 1.201 & 0.328 & n.s. \\
\hline & & & emergence*origin & 2 & 0.865 & 0.423 & n.s. \\
\hline & & & $\begin{array}{l}\text { salinity*origin } \\
\text { emergence* } \text { salinity }\end{array}$ & 4 & 0.358 & 0.839 & n.s. \\
\hline & & & ${ }^{*}$ origin & 4 & 2.042 & 0.091 & n.s \\
\hline \multirow[t]{7}{*}{ DW BG } & Ime & sqrt & emergence & 1 & 20.036 & $<0.001$ & $* * *$ \\
\hline & & & salinity & 1 & 0.801 & 0.7871 & n.s. \\
\hline & & & origin & 2 & 37.318 & $<0.001$ & $* * *$ \\
\hline & & & emergence*salinity & 2 & 1.224 & 0.322 & n.s. \\
\hline & & & emergence*origin & 2 & 0.710 & 0.493 & n.s. \\
\hline & & & $\begin{array}{l}\text { salinity*origin } \\
\text { emergence* }{ }^{*} \text { salinity }\end{array}$ & 4 & 0.664 & 0.617 & n.s. \\
\hline & & & *origin & 4 & 0.591 & 0.670 & n.s \\
\hline \multirow[t]{7}{*}{ DW Total } & Ime & sqrt & emergence & 1 & 15.312 & 0.001 & $* *$ \\
\hline & & & salinity & 1 & 0.180 & 0.843 & n.s. \\
\hline & & & origin & 2 & 39.652 & $<0.001$ & $* * *$ \\
\hline & & & emergence*salinity & 2 & 1.150 & 0.343 & n.s. \\
\hline & & & emergence*origin & 2 & 0.182 & 0.834 & n.s. \\
\hline & & & $\begin{array}{l}\text { salinity* origin } \\
\text { emergence* salinity }\end{array}$ & 4 & 0.690 & 0.600 & n.s. \\
\hline & & & *origin & 4 & 1.393 & 0.238 & n.s \\
\hline $\mathrm{AG} / \mathrm{BG}$ ratio & Ime & sqrt & emergence & 1 & 1.151 & 0.300 & n.s. \\
\hline
\end{tabular}




\begin{tabular}{|c|c|c|c|c|c|c|c|}
\hline & & & salinity & 1 & 0.460 & 0.670 & n.s. \\
\hline & & & origin & 2 & 0.919 & 0.401 & n.s. \\
\hline & & & emergence*salinity & 2 & 0.726 & 0.500 & n.s. \\
\hline & & & emergence*origin & 2 & 1.577 & 0.210 & n.s. \\
\hline & & & $\begin{array}{l}\text { salinity* }{ }^{*} \text { origin } \\
\text { emergence* }{ }^{*} \text { salinity }\end{array}$ & 4 & 0.344 & 0.848 & n.s. \\
\hline & & & *origin & 4 & 1.355 & 0.252 & n.s \\
\hline \# shoots & glmer & n.a. & emergence & 1 & $0.285^{1}$ & 0.593 & n.s. \\
\hline & & & salinity & 1 & 1.491 & 0.222 & n.s. \\
\hline & & & origin & 2 & 10.793 & 0.004 & $* *$ \\
\hline & & & emergence* salinity & 1 & 0.013 & 0.910 & n.s. \\
\hline & & & emergence*origin & 2 & 0.341 & 0.843 & n.s. \\
\hline & & & $\begin{array}{l}\text { salinity*origin } \\
\text { emergence*salinity }\end{array}$ & 2 & 1.459 & 0.482 & n.s. \\
\hline & & & ${ }^{*}$ origin & 2 & 0.162 & 0.922 & n.s \\
\hline RGR WW & Ime & sqrt & emergence & 1 & 17.810 & $<0.001$ & $* * *$ \\
\hline & & & salinity & 1 & 1.030 & 0.457 & n.s. \\
\hline & & & origin & 2 & 1.770 & 0.174 & n.s. \\
\hline & & & emergence*salinity & 2 & 0.690 & 0.518 & n.s. \\
\hline & & & emergence*origin & 2 & 0.290 & 0.746 & n.s. \\
\hline & & & $\begin{array}{l}\text { salinity*origin } \\
\text { emergence*salinity }\end{array}$ & 4 & 0.730 & 0.572 & n.s. \\
\hline & & & *origin & 4 & 2.230 & 0.068 & n.s. \\
\hline $\begin{array}{l}\text { Rhizome } \\
\text { length }\end{array}$ & Ime & none & emergence & 1 & 2.033 & 0.156 & n.s. \\
\hline & & & salinity & 1 & 2.948 & 0.161 & n.s. \\
\hline & & & origin & 2 & 8.581 & $<0.001$ & $* * *$ \\
\hline & & & emergence*salinity & 1 & 0.481 & 0.489 & n.s. \\
\hline & & & emergence* origin & 2 & 0.101 & 0.903 & n.s. \\
\hline & & & $\begin{array}{l}\text { salinity* origin } \\
\text { emergence* salinity }\end{array}$ & 2 & 0.250 & 0.779 & n.s. \\
\hline & & & *origin & 2 & 0.800 & 0.451 & n.s. \\
\hline $\begin{array}{l}\text { Longest } \\
\text { shoot }\end{array}$ & Ime & none & emergence & 1 & 1.189 & 0.277 & n.s. \\
\hline & & & salinity & 1 & 1.721 & 0.260 & n.s. \\
\hline & & & origin & 2 & 9.918 & $<0.001$ & $* * *$ \\
\hline & & & emergence*salinity & 1 & 0.543 & 0.462 & n.s. \\
\hline & & & emergence*origin & 2 & 0.450 & 0.638 & n.s. \\
\hline & & & $\begin{array}{l}\text { salinity*origin } \\
\text { emergence* }{ }^{*} \text { salinity }\end{array}$ & 2 & 0.332 & 0.718 & n.s. \\
\hline & & & ${ }^{*}$ origin & 2 & 0.670 & 0.513 & n.s. \\
\hline
\end{tabular}




\section{Figure 1}

Origin of the Zostera noltii plants used in the experiments (experiment 1: only Oosterschelde, experiment 2: all three populations)

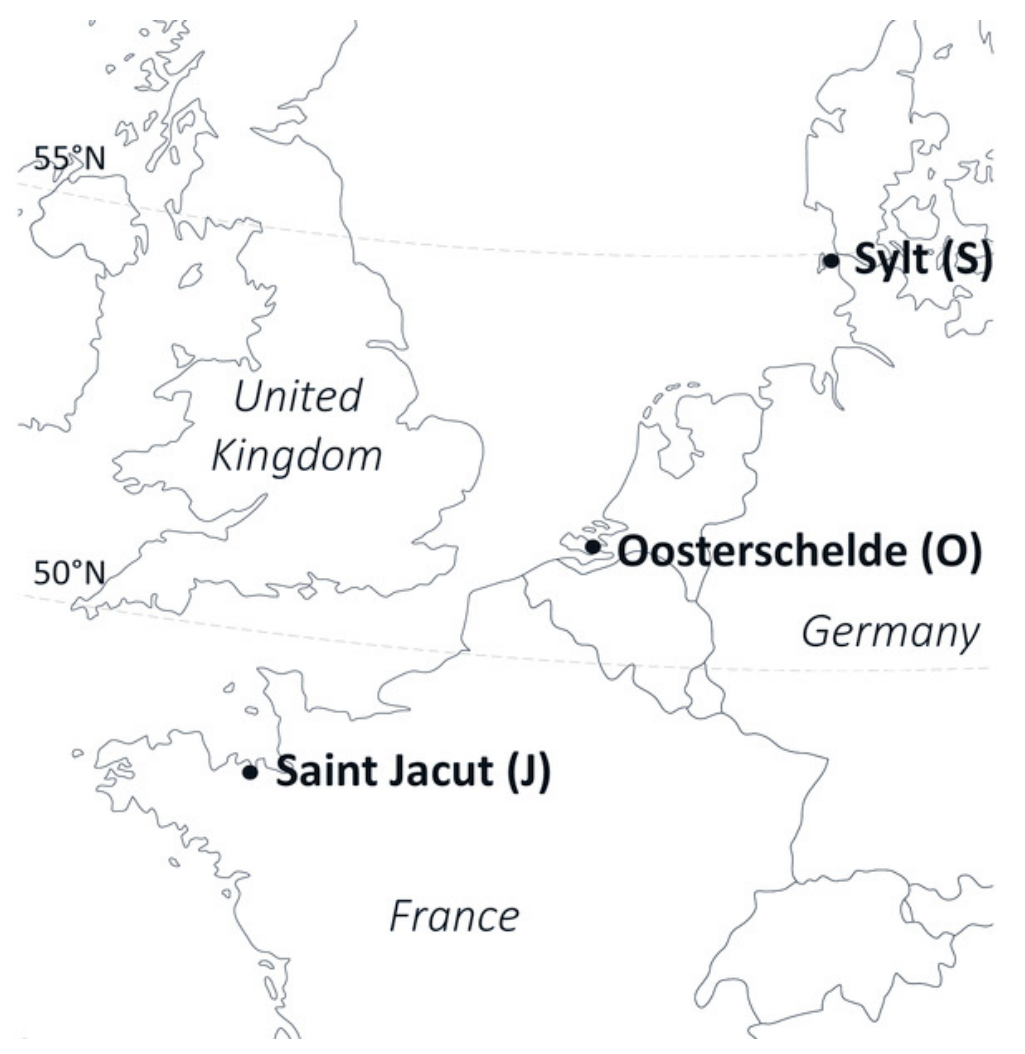




\section{Figure 2}

Experimental set-up of experiment 1 and 2

(A) Set-up of experiment 1 testing emergence $(0,4,6$ and $8 \mathrm{~h}$ per $12 \mathrm{~h}$ ) and shading ( 0 and $75 \%$ shading of $217 \pm 31 \mu \mathrm{E} \mathrm{m}^{-2} \mathrm{~s}^{-1}$, shown as grey shading) in a nested design with 5 true replicates and 4 pseudoreplicates. (B) Set-up of experiment 2 testing 3 populations of origin ( $\mathrm{S}=\mathrm{Sylt}, \mathrm{O}=$ Oosterschelde, $\mathrm{J}=\mathrm{St}$ Jacut) nested in 2 replicated emergence regimes $(0$ and $8 \mathrm{~h}$ emergence per $12 \mathrm{~h}$ ), nested in 3 salinities (25, 30 and 35). An experimental plant unit (EPU) consists of two Zostera noltii shoots (of which one is the apical shoot), plus $1 \mathrm{~cm}$ of the adjacent rhizome internode (drawing courtesy of Vanessa González-Ortiz).

A.
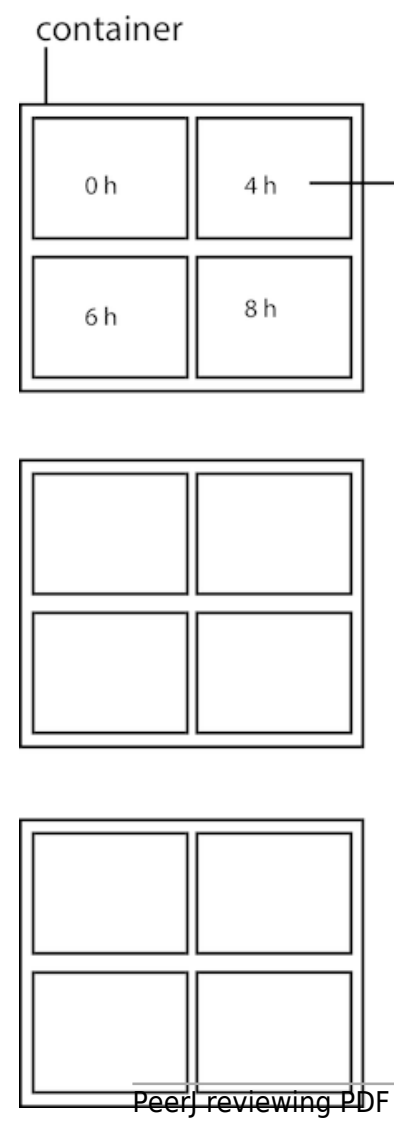

B.

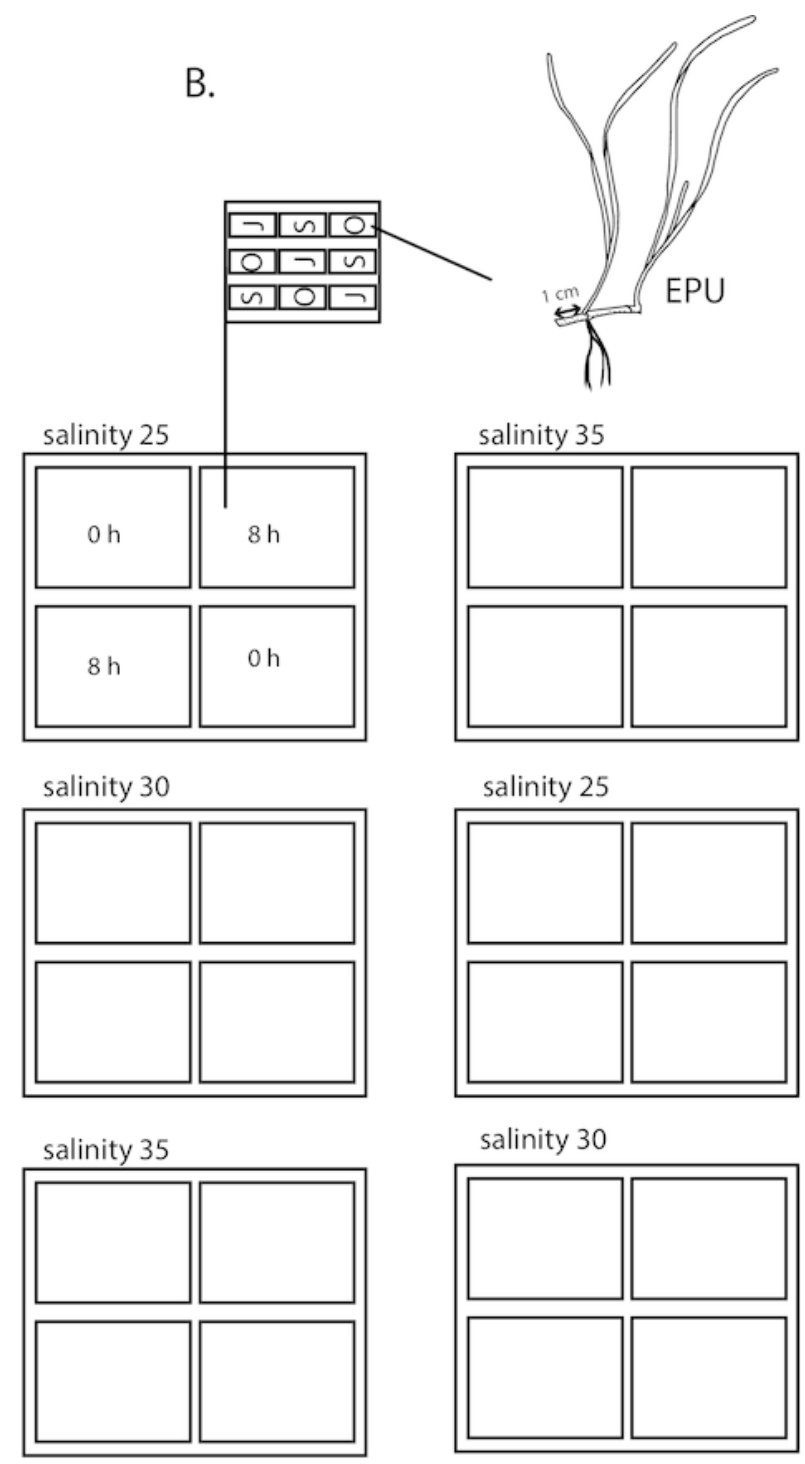




\section{Figure 3}

Zostera noltii development after 60 days in relation to emergence time (x-axis) under light (grey bars) and shaded (black bars) conditions.
A) Aboveground biomass, B) belowground biomass, C) Total biomass, D) aboveground/belowground (AG/BG) biomass ratio, E) Shoot numbers (\# shoots), F) Relative growth rate (RGR) of wet weight (WW), G) Rhizome length and H) Longest shoot length. Statistical results are displayed in the upper right corner of each panel, $0.01<\mathrm{P}<0.05=*$, $0.001<\mathrm{P}<0.01=* * . \mathrm{P}<0.001=* * *$. Detailed statistical results are displayed in table 1. Error bars represent standard errors (SEM). 

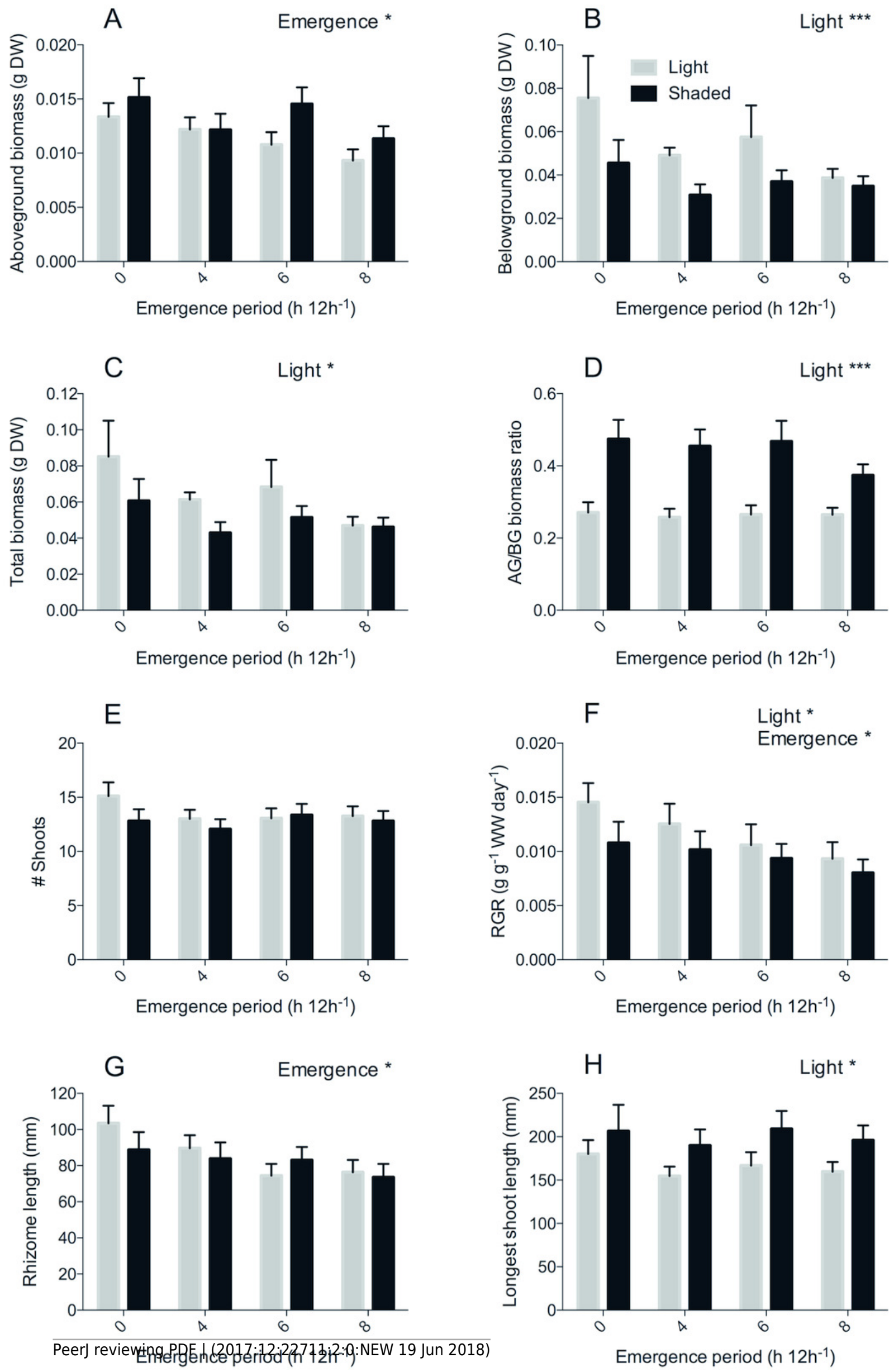


\section{Figure 4}

Zostera noltii growth response after 75 days of combined salinity and emergence treatment.

Salinity treatments are pooled as no significant differences were found between treatments of all measured parameters (Table 2). Locations of origin are displayed in the following colors: Saint Jacut in black, Oosterschelde in light grey and Sylt in dark grey. A) Aboveground biomass, B) belowground biomass, C) Total biomass, D) aboveground/belowground (AG/BG) biomass ratio, E) Shoot numbers (\# shoots), F) Relative growth rate (RGR) of wet weight (WW), G) Rhizome length and H) Longest shoot length. Statistical results are displayed in the upper right corner of each panel, $0.01<\mathrm{P}<0.05=*, 0.001<\mathrm{P}<0.01=* * . \mathrm{P}<0.001=* * *$. Error bars represent standard errors (SEM). 


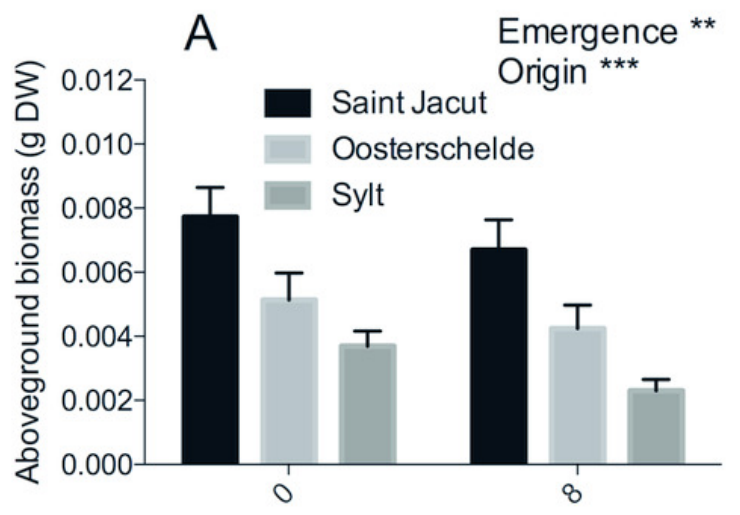

Emergence period $\left(\mathrm{h} 12 \mathrm{~h}^{-1}\right)$

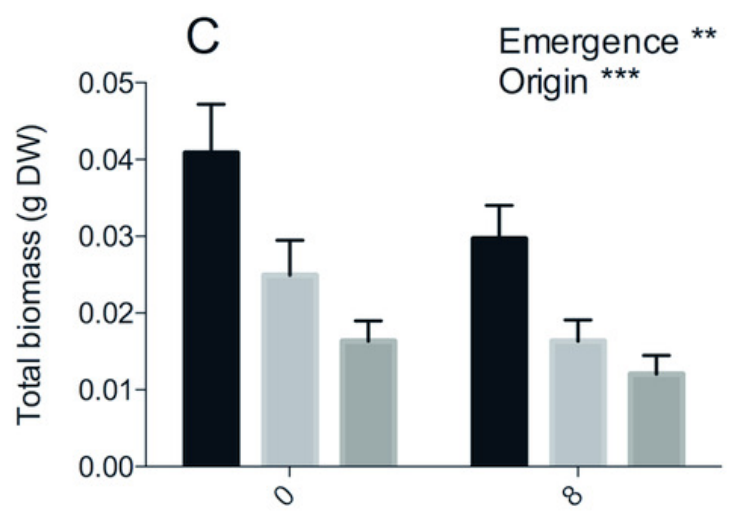

Emergence period $\left(\mathrm{h} 12 \mathrm{~h}^{-1}\right)$

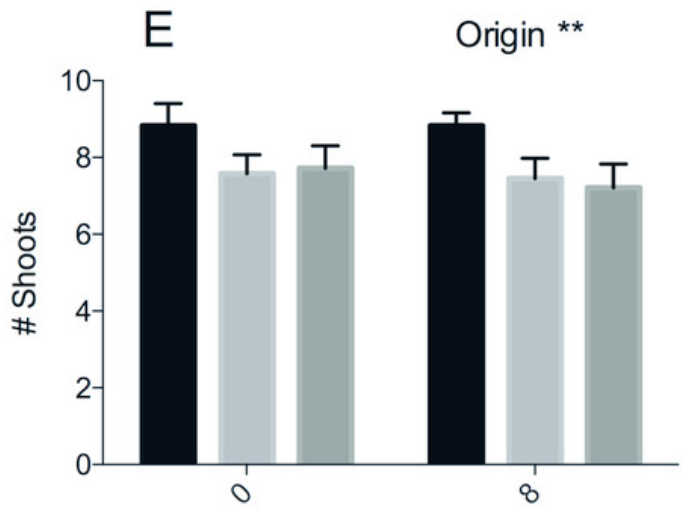

Emergence period (h $\left.12 \mathrm{~h}^{-1}\right)$

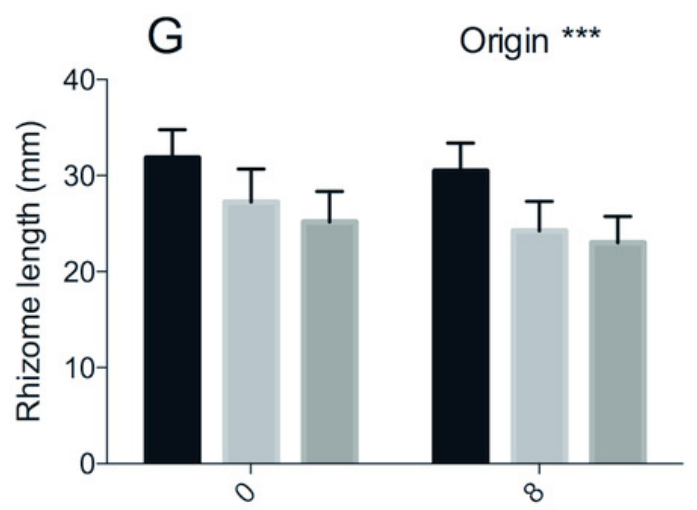

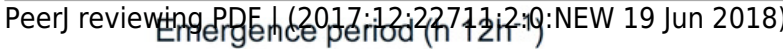

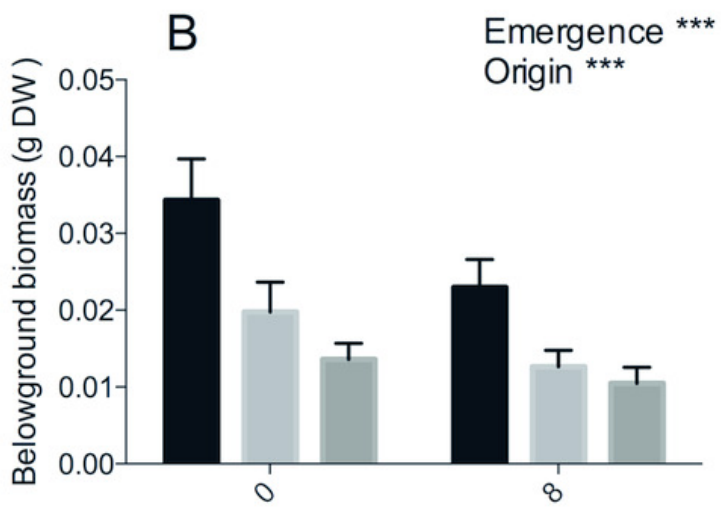

Emergence period $\left(\mathrm{h} 12 \mathrm{~h}^{-1}\right)$

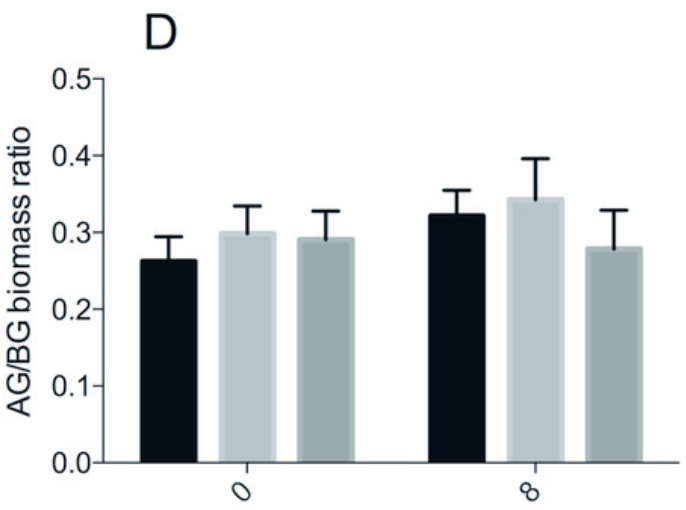

Emergence period $\left(\mathrm{h} 12 \mathrm{~h}^{-1}\right)$

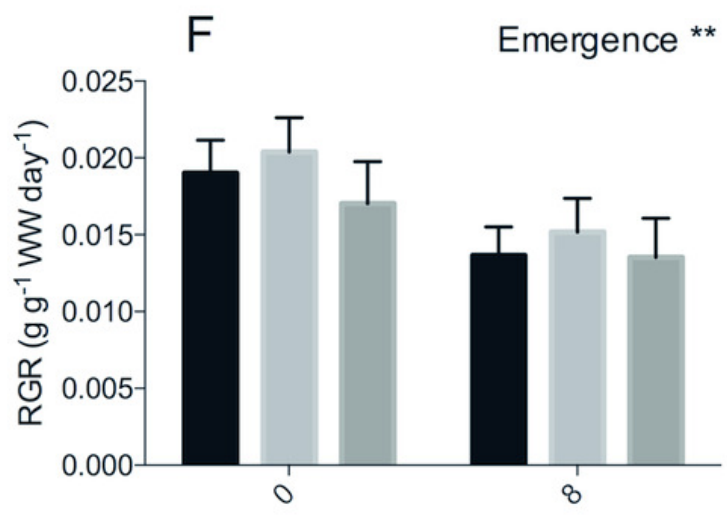

Emergence period ( $\left.\mathrm{h} 12 \mathrm{~h}^{-1}\right)$

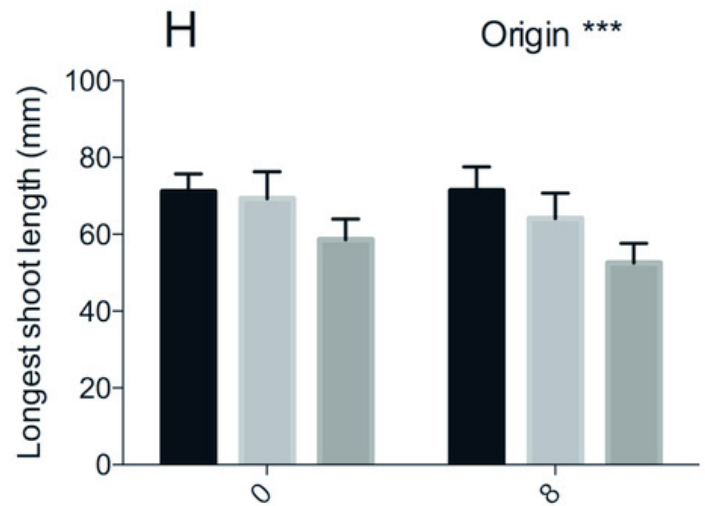

Emergence period ( $\mathrm{h} 12 \mathrm{~h}^{-1}$ ) 